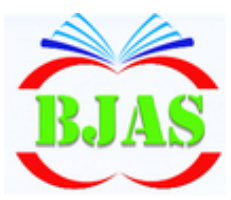

ISSN $1814-5868$
Available online at: http//bjas.bajas.edu.iq

College of Agriculture, University of Basrah

DOi:10.21276/basjas

\title{
TGF-B Super Family Correlation with the Fertility of Iraqi Awassi Ewes
}

\author{
Ismael K. Ajam¹ ${ }^{\text {, Thamer R. S. Al-Jubouri² \& Qayssar H. Ghayyib }}{ }^{3}$ \\ ${ }^{1}$ Department of Pathological analyzes, Islamic University, Iraq \\ ${ }^{2}$ Department of Animal Production, College of Agriculture, University of Al-Qasim Green, \\ ${ }^{3}$ Department of Dairy Science and Technology, College of Food Sciences, University of Al- \\ Qasim Green, Iraq
}

*Corresponding author e-mail: thamerradhi@agre.uoqasim.edu.iq

Received 15 March 2019; Accepted 24 May 2019; Available online 4 September 2019

\begin{abstract}
This study was conducted in Barakat Abu al Fadhl Al- Abbas station (AS) for raising sheep/a subsidiary of Al- Kafeel Company for General Investment and livestock services in Holy Karbala province and Babylon Province It was undertaken on Awassi sheep for between October, 2013 to May, 2014 to investigate the polymorphism of TGF-B gene and its association with reproductive traits of Awassi sheep. Blood samples were collected from (80) ewes included 35 samples of Awassi ewes producing twins (pure breed), 21 samples of Awassi ewes producing twins lambs (hybrid breed), also 25 samples of Awassi ewes producing single lambs (pure breed), with age (2 .5- 5) years. DNA samples were extracted from each blood sample of sheep. Reference PCR primers were utilized to amplify segments in TGF-B Super Family gene. Then, AFLP technique was performed for each PCR fragment. The results indicated that two genotypes for each of the fragments of TGF-B Super Family gene (AF and FF) were identified. TGF-B Super Family gene revealed two fragments (156 and $245 \mathrm{bp}$ ) for FF genotypes and three fragments (156, 254 and $410 \mathrm{bp}$ ) for AF genotypes. PCR- AFLP methods detected two genotypes (AF and FF) with predominant of AF genotype in Awassi ewes producing twin, and this study refers to utilizing TGF-B gene as good genetic markers and their correlation with high fertility and twins producing Awassi sheep.
\end{abstract}

Keywords: Fertility traits, Polymorphism, sheep, TGF-B gene.

\section{Introduction}

Awassi is the main sheep breeds in many countries in the middle east. Although this breed is characterized by slow growth, low fertility and low milk production, their ability to survive and reproduce under condition of drought and extreme climate fluctuations is remarkable (Yousif et al., 2013). Litter size and lamb growth are important economic traits in sheep breeding and reproduction, the ovulation rate can be genetically regulated by 
a set of genes, called fecundity gene (AlThabhawee et al., 2014). Molecular genetics can overcome these limitations offering new opportunities to the improvement of reproductive traits, as it supplies tools to analyze genetic variability directly at the DNA level with the possibility of detecting the individual genes influencing the reproductive characteristics (Asadpour et al., 2012).

Multiple ovulations in mammals is a complex trait influenced by genetic and environmental factors. Genetic mutation of the first gene growth differentiation factor of TGF-B super family (transforming growth factor-B) with major effects on the ovulation rate in sheep was identified (Paulini \& Melo, 2011). The TGF-B super family contains over 35 members, many of which have shown to be important Role in regulating fertility. TGF$\mathrm{B}$ is oocyte specific growth factor that appears to play key roles in granulosa cell development and fertility in most mammalian species (Ghaderi et al., 2010). It has been proposed that TGF-B promotes theca cell proliferation as well as decreases steroidogenesis and may, therefore, also prevent theca cells from premature differentiation during folliculogenesis. It was also demonstrated that genetic alterations, e.g., mutations in the TGF-B gene lead to infertility in sheep due to ovarian dysfunction (Otsuka et al., 2011). As a result of their role in the folliculogenesis, the availability of TGF-B polymorphisms can be very useful in the study of animal reproductive genetics and physiology (Silva et al., 2010). Therefore the aim of this study is to investigate the possibility of an association between the polymorphism of TGF-B and reproductive traits in Awassi sheep.

\section{Materials \& Methods}

\section{Animals}

Eighty Iraqi sexually mature healthy Awassi sheep were included in this study. These sheep were grazed in the field of the independent department of Holy Al-Hussein in Karbala and Babylon Provinces for a period from October 2013 to May 2014. Sheep divided to 35 samples of pure Awassi ewes producing twins 21 samples of cross Awassi ewes producing twins' lambs, and finale 25 samples of pure Awassi ewes producing single lambs aged (2.5 - 5) years.

\section{Blood collection}

Venous jugular blood samples (4 ml per sheep) were collected from 80 Awassi sheep. The blood samples were placed in EDTA tubes as anticoagulants. Blood samples were transported to the laboratory in an ice box for DNA extraction. Genomic DNA was extracted from the whole blood by by AlShuhaib (2017). Then dissolved in TE buffer [10 mmol / 1 Tris-HCl (pH 8.0), $1 \mathrm{mmol} / 1$ EDTA (pH 8.0)] and kept at $-20^{\circ} \mathrm{C}$ for further analysis. Primers and PCR amplification One pair of primer was used to amplify TGF-B gene on in the reference gene by Hanrahan et al., (2004). The expected amplification fragment size was 462 bp. The primer sequences used were F:5'-GAA GAC TGG TAT GGG GAA ATG-3' and R5'-CCA ATC TGC TCC TAC ACA CCT-3' (Hanrahan et al., 2004).

Polymerase chain reaction was carried out in $25 \mu \mathrm{l}$ volume containing approximately 2.5 $\mu l$ of $10 \times$ PCR buffer $(50 \mathrm{mmoV} 1 \mathrm{KCl}, 10$ mmoV 1 Tris- $\mathrm{HCl}(\mathrm{pH} 8.0), 0.1 \%$ Triton X100), $1.5 \mathrm{mmol} / 1$ of $\mathrm{Mg} 12.200 \mu \mathrm{mol} / 1$ of each dNTP, $1 \mu \mathrm{mol} / 1$ of each primer, $50 \mathrm{ng}$ of genomic DNA and $2 \mathrm{U}$ of Taq DNA polymerase. Amplification conditions were as 
follows: initial denaturation at $95^{\circ} \mathrm{C}$ for $4 \mathrm{~min}$ followed by 30 cycles of denaturation at 94 ${ }^{\circ} \mathrm{C}$ for $30 \mathrm{~s}$, annealing at $58{ }^{\circ} \mathrm{C}$ for $30 \mathrm{~s}$, extension at $72{ }^{\circ} \mathrm{C}$ for $30 \mathrm{~s}$ with a final extension at $72^{\circ} \mathrm{C}$ for $5 \mathrm{~min}$ on Master cycler (Eppendorf AG, Hamburg, Germany) PCR products were electrophoresed on $2 \%$ agarose at $75 \mathrm{~V}$ for 1 hour and visualized by ethidium bromide. Photos were taken using photo documentation unit.

\section{AFLP Analysis}

Digestion with restriction enzyme used for TGF-B is Hha I. Digestion reaction contains 5 $\mu \mathrm{l}$ of PCR product, $5 \mathrm{U}$ appropriate enzyme, 2 $\mu \mathrm{l}$ buffer $10 \mathrm{x}$ in $20 \mu \mathrm{l}$ final volume incubated for 3 to $6 \mathrm{~h}$ at $37{ }^{\circ} \mathrm{C}$. After digestion with restriction enzymes, all products were separated by using electrophoresis in $2 \%$ agarose gel and visualized with ethidium bromide.

\section{Statistical Analyses}

The genotype and allele frequencies of TGFB gene polymorphisms and $G$ statistic test were used to determine whether the

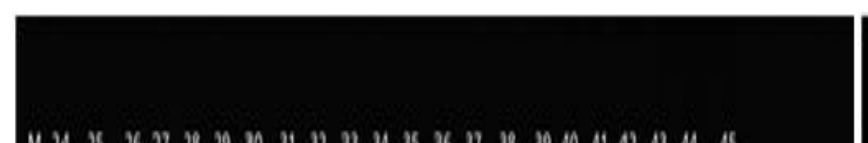

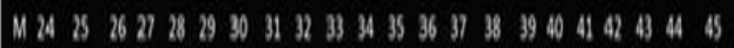

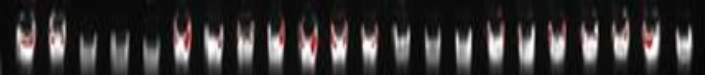

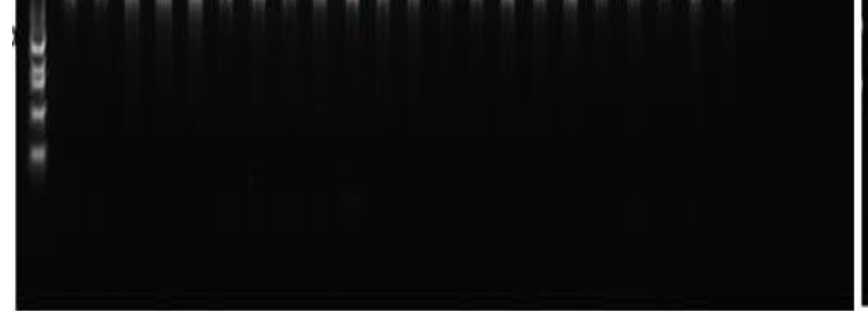

populations are in Hardy- Weinberg equilibrium using POPGENE32 software 19 (Yeh et al ., 1999).

\section{Results \& Discussion}

In this study, simple manual procedures are used to isolate DNA, the concentration and purity of the isolated DNA are tested for further molecular analysis, such as PCR (Fig. 1).

\section{PCR Amplified Products of the Exon 1 of TGF-B}

A DNA fragment with the size of $462 \mathrm{bp}$ was amplified from exon 1 of TGF-B, all the individuals were generated one obvious band (Fig. 2), indicating the high specificity of the selected specific primers.

PCR-AFLP method was used to investigate the mutations, which includes digestion with restriction enzymes Hha 1. TGF-B exon 1 agarose gel electrophoresis reveal variation within this amplicons. Two fragments (156 bp and $245 \mathrm{bp}$ ) were produced by the wild type and three fragments (156 bp, $254 \mathrm{bp}$ and 410 bp) by heterozygous (polymorphism) (Fig. 3).

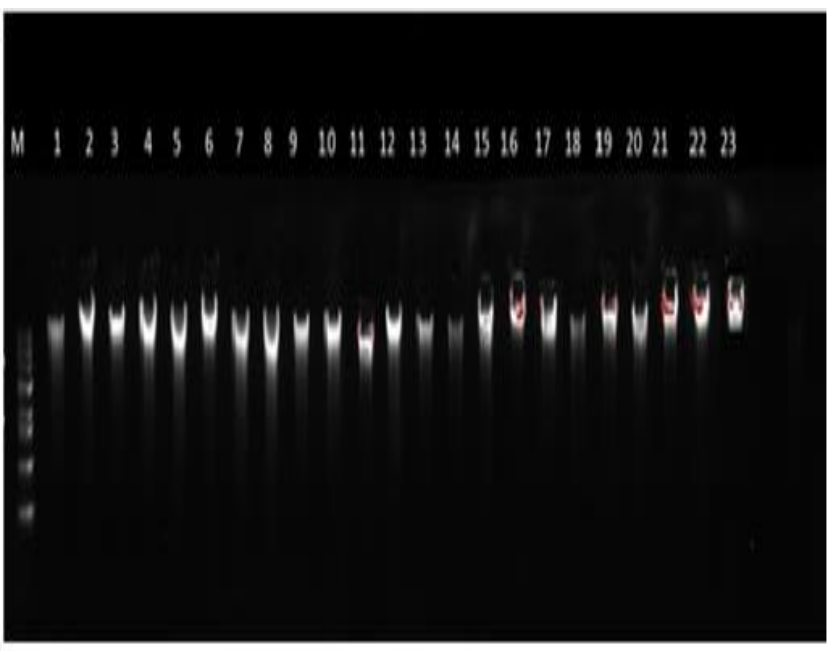

Fig. (1): Agarose gel electrophoresis of gDNA extracted using the manual procedure. M; Refers to DNA size marker, lane 1 into lane 23 refers to extracted gDNA samples from Awassi ewes (producing single lambs), lane 24 into lane 45 refers to extracted gDNA samples from pure Awassi ewes producing twins, Electrophoresis conditions: Agarose concentration 0.8\%, power applied: $75 \mathrm{~V}(4.1 \mathrm{~V} / \mathrm{cm})$, time of run: $1 \mathrm{hr}$. Staining method; precast ethidium bromide. 


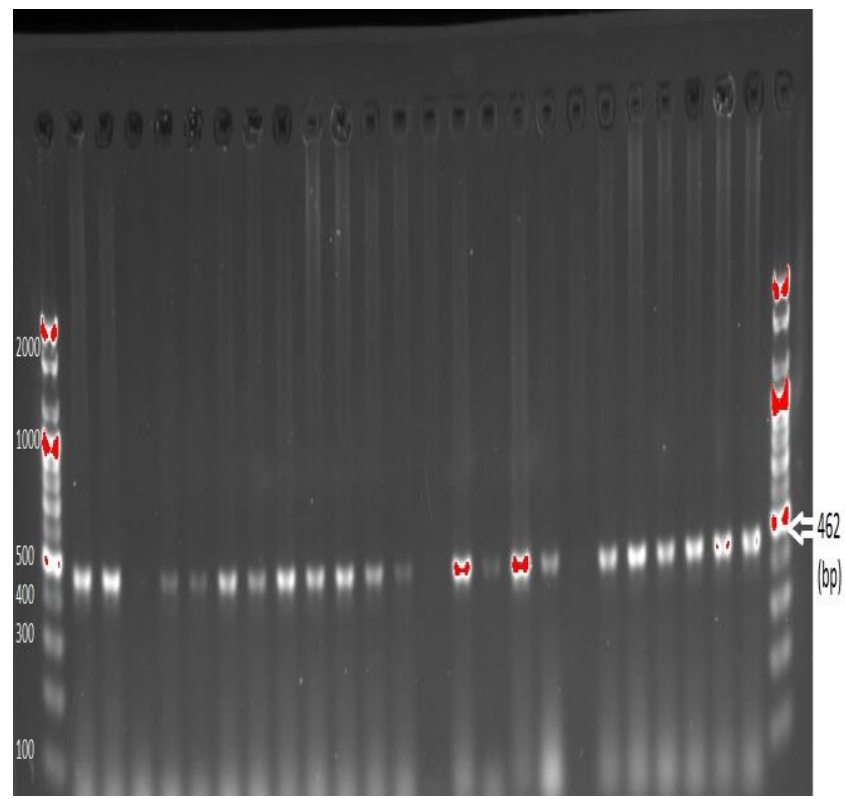

Fig. (2): Agarose gel electrophoresis of TGF-B exon 1 PCR fragments. M; Refers to DNA size marker, Electrophoresis conditions: Agarose concentration $2 \%$, power applied: $100 \mathrm{~V}(7 \mathrm{~V}$. $\mathrm{cm}^{-1}$ ), time of run: 45 min. Staining method; precast ethidium bromide.

AFLP analysis reveals two genotypes (AF and $\mathrm{FF}$ ) in all screened TGF-B exon 1 of sheep. The overall ratio of the genotypes AF was the highest (78\%) from Awassi ewes producing twin, (100\%) from Awassi ewes producing twin (hybrid breed), (19\%) from Awassi ewes producing single lambs, while, the genotype FF (21\%) from Awassi ewes producing twin and $(0 \%)$ from Awassi ewes producing twin (hybrid breed) and (80\%)

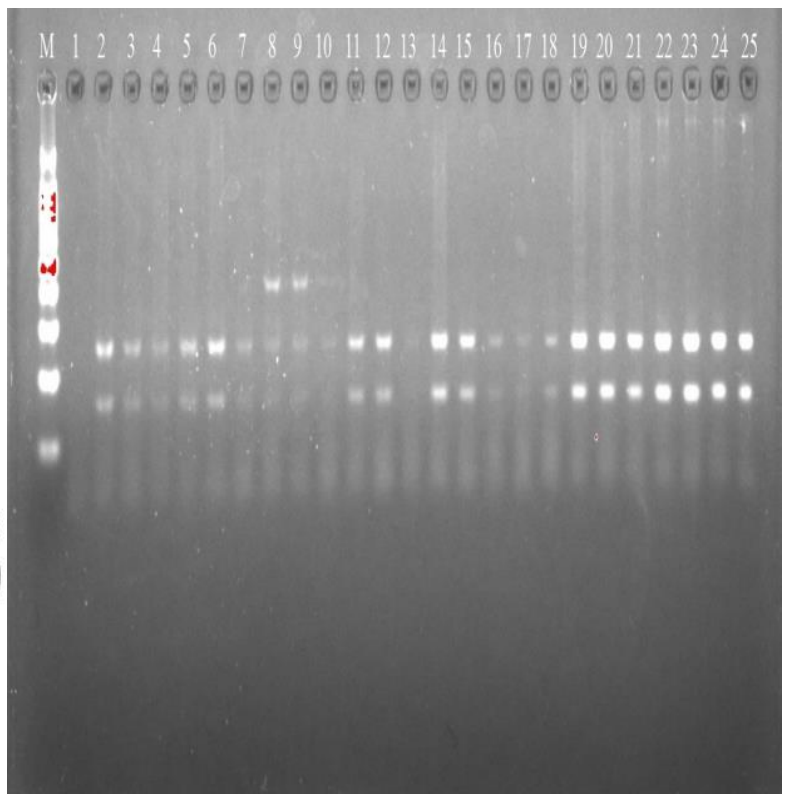

Fig. (3): PCR-AFLP analysis of TGF-B gene exon 1 in Awassi sheep using Hha l. M; Refers to DNA size marker, lane 1 into lane 80 refers to resulted PCR products were digested with $\mathrm{Hha}$ I Electrophoresis conditions: Agarose concentration $2 \%$, power applied: $100 \mathrm{~V}\left(7 \mathrm{~V} . \mathrm{cm}^{-1}\right)$, time of run: 45 min. Staining method; precast ethidium bromide.

from Awassi ewes producing single lambs (Table 1). Genotype and allele frequencies and Hardy-Weinberg test of TGF-B exon 1 is presented in Table (2). The observed frequencies of $\mathrm{A}$ allele were 0.36 and $\mathrm{F}$ allele was 0.64 of which the predominant genotype was AF. The $\chi^{2}$ test showed that the polymorphism of TGF-B exon 1 in Awassi sheep was at Hardy-Weinberg equilibrium for this locus in the studied population (Table 2).

Table (1): Distribution of TGF-B exon 1 polymorphism with different samples of sheep.

\begin{tabular}{|c|c|c|c|c|c|c|}
\hline \multirow{2}{*}{$\begin{array}{l}\text { - genotype } \\
\text { (group) }\end{array}$} & \multicolumn{2}{|c|}{$\mathrm{AF}$} & \multicolumn{2}{|c|}{$\mathrm{FF}$} & \multirow[t]{2}{*}{ Total } & \multirow{2}{*}{$\begin{array}{c}\text { Chi-square } \\
\left(\chi^{2}\right)\end{array}$} \\
\hline & No. & $\%$ & No. & $\%$ & & \\
\hline Twin A & 27 & 78.79 & 7 & 21.21 & 34 & $12.975 * *$ \\
\hline Twin, Hybrid & 20 & 100 & 0 & 0.00 & 20 & $15.00 * *$ \\
\hline Single A & 4 & 19.05 & 17 & 80.95 & 21 & $13.269 * *$ \\
\hline
\end{tabular}


Table (2): The observed, expected, average heterozygosity, $\chi^{2}$ test for Hardy-Weinberg equilibrium, and genotype frequencies of TGF-B exon 1 for the Ovis aries Awassi breed.

\begin{tabular}{ccccccc}
\hline Obs-Het & Exp-Het & Avr-Het & $\begin{array}{c}\text { Nei'-Exp - } \\
\text { Het }\end{array}$ & $\chi^{\mathbf{2}}$ & $\begin{array}{c}\text { Allele A } \\
\text { freq. }\end{array}$ & Allele F freq. \\
\hline 0.7209 & 0.4638 & 0.4611 & 0.4611 & 26.8 & 0.36 & 0.64 \\
\hline
\end{tabular}

Abbreviations: Obs-Het: Observed heterozygocity, Exp-Het: Expected heterozygocity, Avr-Het: Average heterozygocity, Nei-Exp-Het: Nei's expected heterozygocity, freq.: frequency.

In this study, PCR- AFLP method detected two genotypes (AF and FF) with a predominant of AF genotype in producing twins Awassi rams and ewes. TGF-B gene is autosomal that in homozygous state causes sterility and in heterozygous state provides multiple births (Gursel et al., 2011). neutralize TGF-B affects the activity of the Corpus luteum and therefore in addition to its impact on follicle growth, its effectiveness was also broadened on the active of ovulation and pregnancy induction (Juengel et al., 2004). An asexual TGF-B gene on chromosome 5 has a mutation that can increase the rate of ovulation in heterozygous ewes and sterility in homozygous ewes (Hanrahan \& Owen, 1985). Moreover, partial defects in TGF-B genes were associated with the increased ovulation rate in sheep (XueQin et al., 2009).

Hanrahan et al. (2004) reported eight DNA variants in TGF-B of Cambridge and Belclare sheep including from G1 to G8, and showed that Cambridge and Belclare sheep carrying a mutation in the gene (FecGH). Exons 1 and 2 of TGF-B gene increase ovulation rate of heterozygous sheep and the lack of fertility in homozygous sheep. G8 variant also known as FecGH where serine converted to phenylalanine at the base 395 which replaced an uncharged polar amino acid with a nonpolar one at base 77 of the mature coding region and may change the function of TGF-B in sheep (Dutta et al., 2013; López-Ramírez et al., 2014). TGF-B gene variant can be applied in breeding programs by gene-assisted selection (GAS), aiming towards the improvement of sheep reproductive potential and production (Silva et al., 2010). Kolosov $\mathrm{Yu}$ et al. (2015) determine the TGF-B polymorphism in Russian sheep breeds polymorphism was identified by PCR- RFLP method, and AG and GG genotypes were detected in this study.

\section{Conclusion}

This study refers to utilizing TGF-B gene as good genetic markers and correlation with high fertility and twins producing in Awassi sheep.

\section{Acknowledgments}

This study was supported by Barakat Abu AlFadhl Al-Abbas (AS) Station for raising sheep, Al-Khafeel (Karbala, Iraq) also a College of Agriculture, Al-Qasim Green University.

Conflict of interest: The authors declare that they have no conflict of interest.

Ethical approval: all applicable national and international guidelines for the care and use of animals were followed.

\section{References}

Al-Shuhaib, M.B.S.A. (2017). A universal, rapid, and inexpensive method for genomic DNA isolation from the whole blood of 
mammals and birds. J. Genet., 96: 171176.

Al-Thabhawee, A.H.; Samaka, H.M. \& Kadhim, H.M. (2014). Detection of (FecB) gene polymorphism in local sheep breed at different area of Iraq. MRVSA, 3(1): 1520.

Asadpour, R.; Jafari-Joozani, R.; Alijani, S. \& Mahmodi, H. (2012). Detection of polymorphism in Booroola gene $(\mathrm{FecB})$ and its association with litter size in zel sheep breed in Iran. Slovak J. Anim. Sci., 45(2): 63-66.

Dutta, R.; Das, B.; Laskar, S.; Kalita,D.J.; Borah, P.; Zaman, G. \& Saikia, P.D. (2013). Polymorphism, sequencing and phylogenetic characterization of growth differentiation factor 9 (GDF9) gene in Assam Hill goat Polymorphism, sequencing and phylogenetic characterization of growth differentiation factor 9 (GDF9) gene in Assam Hill goat. AJB., 12(50): 6894-6900.

Ghaderi, A.; Nasiri, B.M.T.; Mirzadeh, K.H.; Fayazi, J. \& Sadr, A.S. (2010). Identification of the GDF9 mutation in two sheep breeds by using polymerase chain reaction- restriction fragment length polymorphism (PCR-RFLP) technique. AJB, 9(47): 8020-8022.

Gursel, F.E., Akis, A.; Durak, H.; Mengi, A. \& Oztabak, K. (2011): Determination of BMP-15, BMPR-1B and GDF-9 Gene Mutations of the Indigenous Sheep Breeds in Turkey. Kafkas Kafkas Üniversitesi Veteriner Fakültesi Dergisi, 17(5): 725729.

Hanrahan, J.P.; Gregan, S.M.; Mulsant, P.; Mullen, M.; Davis, G.H.; Powell, R. \& Galloway, S. (2004). Mutations in the genes for oocyte derived growth factors GDF9 and BMP15 are associated with both increased ovulation rate and sterility in Cambridge and Belclare sheep (Ovis aries). Biol. Reprod., 70: 900-909.

Hanrahan, J.P. \& Owen, J.B. (1985). Variation and repeatability of ovulation rate in Cambridge ewes. Anim. Prod., 40: 529.

Juengel, J.L.; Hudson, N.L.; Whiting, L. \& McNatty, K.P. (2004). Effects of immunization against bone morphogenetic protein 15 and growth differentiation factor 9 on pregnancy in Ewes. Biol. Reprod., 70: 557-561.

Kolosov Yu, A.; Getmantseva, L.V.; Shirockova, N.V.; Klimenko, A.; Yu, B.S.; Usatov, A.V.; Yu, K.A.; Bakoev, N.F. \& Leonova, M.A. (2015). Polymorphism of the GDF9 gene in Russian sheep breeds. J. Cytol. Histol., 6: 305. doi:10.4172/21577099.1000305 .

López-Ramírez, R.B.; Magaña-Sevilla, H.F.; Zamora-Bustillos, R.; Ramón-Ugalde, J.P. \& González-Mendoza, D. (2014). Analysis of the 3' end regions of the GDF9 and BMPR1B genes in Blackbelly sheep from Yucatán, Mexico. Cien. Inv. Agr., 41(1): 123-128.

Otsuka, F.; McTavish, K.J. \& Shimasaki, S. (2011). Integral role of GDF-9 and BMP15 in ovarian function. MRD, 78: 9-21.

Paulini, F. \& Melo, E. (2011). The role of oocyte-secreted factors GDF9 and BMP15 in follicular development and oogenesis. Reprod. Dom. Anim., 46: 354-361.

Silva, B. D. M.; Castro, E.A.; Souza, C.J.H.; Paiva, S.R.; Sartori, R.; Franco, M.M.; Azevedo, H.C.; Silva, T.A.S.N.; Vieira, A. 
M.C. ; Neves, J.P. \& Melo, E.O. (2010). A new polymorphism in the Growth and Differentiation Factor 9(GDF9) gene is associated with increased ovulation rate and prolificacy in homozygous sheep. ISAG, 42: 89-92.

Xue-Qin, R.; Jian-bin, L.; Zhi-Yong, D.U.; Qing Cheng, Q. \& Jia-Fu, W. (2009). Diversity of bmp15 and gdf9 genes in white goat of Guizhou province and evolution of the encoded proteins. Zool. Res., 30(6): 593-602.
Yeh, F.C.; Yang, R. \& Boyle, T. (1999). POPGENE: Version 1.31. Microsoft Window-based Freeware for Population Genetic Analysis, Univ. Alberta. Edmonton, AB.

Yousif, M.S.; Al-Barzinji \& Othman,G.U. (2013). Genetic polymorphism in $\mathrm{FecB}$ gene in Iraqi sheep breeds using RFLPPCR technique. IOSR-JAVS, 2(4): 46-48. 